\title{
Application of fracture mechanics for energetic effects predictions while wood sawing
}

\author{
Kazimierz A. Orlowski • Tomasz Ochrymiuk • \\ Anthony Atkins $\cdot$ Daniel Chuchala
}

Received: 2 January 2012/Published online: 11 May 2013

(C) The Author(s) 2013. This article is published with open access at Springerlink.com

\begin{abstract}
In the classical approach, energetic effects (cutting forces and cutting power) of wood sawing process are generally calculated on the basis of the specific cutting resistance, which is in the case of wood cutting the function of more or less important factors. On the other hand, cutting forces (or power-more interesting from energetic point of view) could be considered from a point of view of modern fracture mechanics. Cutting forces may be employed to determine not only toughness but also shear yield strength, which are then applied in the models. Furthermore, forecasting of the shear plane angle for the cutting models, which include fracture toughness in addition to plasticity and friction, broadens possibilities of energetic effects modelling of the sawing process even for small values of the uncut chip. Mentioned models are useful for estimation of energetic effects of sawing of every kinematics. However, for band saws and circular sawing machines, the chip acceleration power variation as a function of mass flow and tool velocity ought to be included in analysis of sawing at larger cutting speeds.
\end{abstract}

\footnotetext{
K. A. Orlowski $(\bowtie) \cdot$ D. Chuchala

Department of Manufacturing Engineering and Automation, Faculty of Mechanical Engineering, Gdansk University of Technology, Narutowicza 11/12, 80-233 Gdansk, Poland

e-mail: korlowsk@pg.gda.pl

T. Ochrymiuk

Department of Renewable Energy, Polish Academy of Sciences, Szewalski Institute of Fluid-Flow Machinery, Gdansk, Poland
}

A. Atkins

School of Construction Management and Engineering, University of Reading, Whiteknights, Reading, Berkshire, UK 


\section{Introduction}

Theoretical and experimental determination of values of forces acting in the cutting process belongs to the basic and simultaneously the most developed field of mechanics of this process. A great number of theoretical works, which were improved and experimentally verified, have been devoted to this problem. In the classical approach, energetic effects (cutting forces and cutting power) of wood sawing process are generally calculated on the basis of the specific cutting resistance $k_{\mathrm{c}}$ (cutting force per unit area of cut) (Fischer 2004; Scholz et al. 2009; Orlowski 2007), which in the case of wood cutting is the function of the following factors: wood species, cutting direction angle (cutting edge position in relation to wood grains), moisture content, wood temperature, tooth geometry, tooth dullness, chip thickness and some others which are less important (Agapov 1983; Orlicz 1988). Many of those traditional models are empirical and based upon limited information employing blades having standard thickness kerfs. Moreover, for each type of sawing kinematics, different values of specific cutting resistance $k_{\mathrm{c}}$ have to be applied (Manžos 1974; Orlicz 1988; Orlowski 2007). On the other hand, cutting forces could be considered from a point of view of modern fracture mechanics (Atkins 2003, 2009; Laternser et al. 2003; Williams 1998; Williams et al. 2010). In the quoted works, modelling of wood cutting process has been described as models with continuous chip formation. On the other hand, Merhar et al. (2011) and Merhar and Bučar (2012) have investigated the conditions of chip propagation or fracture in orthogonal oblique cutting of beech wood with the discontinuous chip formation process.

In analyses of sawing processes in which the offcut formation by shear occurs, Atkins's ideas (2009) can also be applied, for example in the real sawing process on a sash gang saw (Orlowski and Atkins 2007; Orlowski and Palubicki 2009; Orlowski 2010; Orlowski et al. 2010). In this paper, it is proved that cutting power models which are based on modern fracture mechanics are useful for estimation of energetic effects of sawing of every kinematics.

\section{Theoretical background}

Making an assumption that cutting force $F_{\mathrm{c}}$ acting in the middle of the cutting edge is an equilibrium of forces related to the direction of primary motion for a single saw tooth, the mechanical process of material separation from the sawn workpiece, that is, chip formation, can be described by the example of an orthogonal process (two-dimensional deformation). The forces acting on the tooth can be represented in the classical approach by Ernst and Merchant's force circle shown in Fig. 1.

According to Atkins (2009) and Orlowski (2010), furthermore, taking into account that the chips have to be accelerated to the same velocity as the cutting tool velocity $v_{\mathrm{c}}$ (Atkins 2009; Pantea 1999), cutting power for one saw blade during the cutting stroke on a sash gang saw, and during cutting on a band saw machine, because their sawing kinematics are similar (Fig. 2), has the following mathematical formula: 


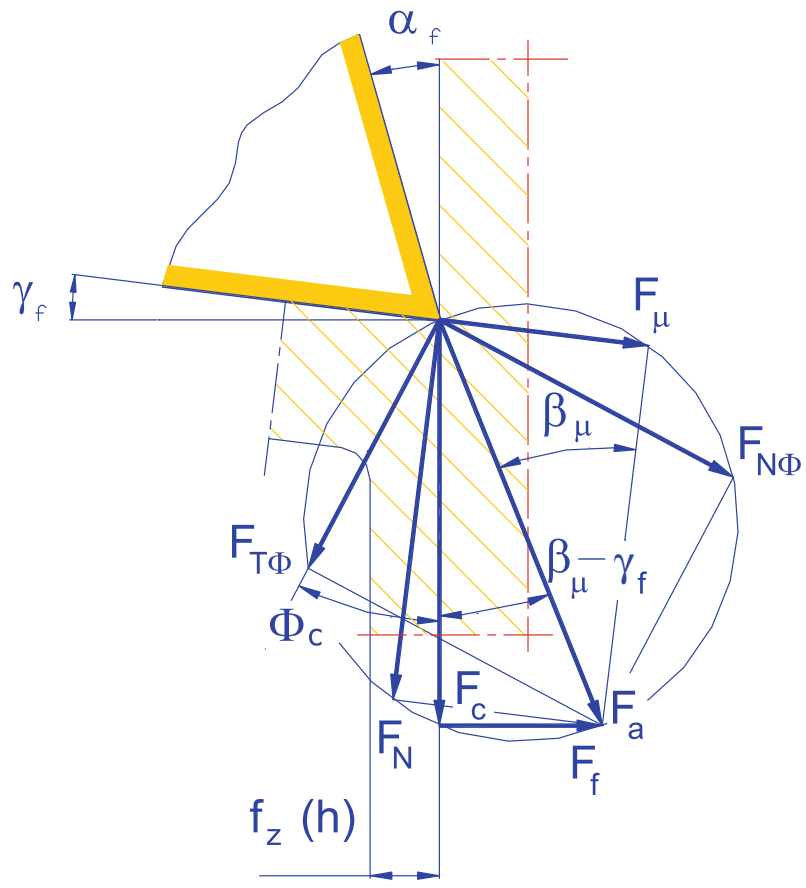

Fig. 1 Simplified cutting process model with Ernst and Merchant's force circle (Grotte and Antonsson 2008): $F_{\mathrm{a}}$ active force, $F_{\mathrm{c}}$ cutting force, $F_{\mathrm{f}}$ thrust force (passive), $F_{\mu}$ friction force on the rake face, $F_{\mathrm{N}}$ normal force to the rake face, $F_{\mathrm{T} \Phi}$ the force required to shear the wood along the shear plane, $F_{\mathrm{N} \Phi}$ normal force on the shear plane, $\alpha_{\mathrm{f}}$ clearance angle, $\Phi_{\mathrm{c}}$ shear angle, $\gamma_{\mathrm{f}}$ rake angle, $\beta_{\mu}$ friction angle

$$
\bar{P}_{\mathrm{cw}}=F_{\mathrm{c}} v_{\mathrm{c}}+P_{\mathrm{ac}}=\left[z_{\mathrm{a}} \cdot \frac{\tau_{\gamma} S_{t} \gamma}{Q_{\text {shear }}} v_{\mathrm{c}} f_{\mathrm{z}}+z_{a} \cdot \frac{R_{\perp} S_{\mathrm{t}}}{Q_{\text {shear }}} v_{\mathrm{c}}\right]+P_{\mathrm{ac}}
$$

where $z_{a}=\left(\frac{H_{\mathrm{p}}}{P}\right)$ is the number of teeth being in contact with the kerf (average) (Dmochowski 1981; Olszak 2008), $H_{\mathrm{p}}$ is workpiece height (cutting depth), $\tau_{\gamma}$ is the shear yield stress, $\gamma$ is the shear strain along the shear plane, which is given by:

$$
\gamma=\frac{\cos \gamma_{\mathrm{f}}}{\cos \left(\Phi_{\mathrm{c}}-\gamma_{\mathrm{f}}\right) \sin \Phi_{\mathrm{c}}}
$$

$f_{\mathrm{z}}$ is feed per tooth (uncut chip thickness $h$ ), $S_{\mathrm{t}}$ is a kerf (the width of orthogonal cut), $\beta_{\mu}$ is friction angle which is given by $\tan ^{-1} \mu=\beta_{\mu}$, with $\mu$ the coefficient of friction, $\gamma_{\mathrm{f}}$ is the rake angle, $\Phi_{\mathrm{c}}$ is the shear angle which defines the orientation of the shear plane with respect to cut surface, $R_{\perp}$ is specific work of surface separation/formation (fracture toughness), and $Q_{\text {shear }}$ is the friction correction:

$$
Q_{\text {shear }}=\left[1-\left(\sin \beta_{\mu} \sin \Phi_{\mathrm{c}} / \cos \left(\beta_{\mu}-\gamma_{\mathrm{f}}\right) \cos \left(\Phi_{\mathrm{c}}-\gamma_{\mathrm{f}}\right)\right)\right]
$$

For least force $F_{\mathrm{c}}$, the shear angle $\Phi_{\mathrm{c}}$ satisfies (Atkins 2003): 


$$
\begin{aligned}
& {\left[1-\frac{\sin \beta_{\mu} \sin \Phi_{\mathrm{c}}}{\cos \left(\beta_{\mu}-\gamma_{\mathrm{f}}\right) \cdot \cos \left(\Phi_{\mathrm{c}}-\gamma_{\mathrm{f}}\right)}\right] \cdot\left[\frac{1}{\cos ^{2}\left(\Phi_{\mathrm{c}}-\gamma_{\mathrm{f}}\right)}-\frac{1}{\sin ^{2} \Phi_{\mathrm{c}}}\right]} \\
& =-\left[\cot \Phi_{\mathrm{c}}+\tan \left(\Phi_{\mathrm{c}}-\gamma_{\mathrm{f}}\right)+Z\right] \cdot\left[\frac{\sin \beta_{\mu}}{\cos \left(\beta_{\mu}-\gamma_{\mathrm{f}}\right)}\left\{\frac{\cos \Phi_{\mathrm{c}}}{\cos \left(\Phi_{\mathrm{c}}-\gamma_{\mathrm{f}}\right)}+\frac{\sin \Phi_{\mathrm{c}} \sin \left(\Phi_{\mathrm{c}}-\gamma_{\mathrm{f}}\right)}{\cos ^{2}\left(\Phi_{\mathrm{c}}-\gamma_{\mathrm{f}}\right)}\right\}\right]
\end{aligned}
$$

in which $Z=\frac{R}{\tau_{\gamma} \cdot f_{z}}$ is the parameter which makes $\Phi_{\mathrm{c}}$ material dependent. Since wood is an anisotropic material, its physical and mechanical properties differ in the three principal directions relative to the trunk of the tree (Fig. 3): longitudinal (L, axial): parallel to tree trunk and parallel to long axis of longitudinally oriented cells (tracheids and fibre tracheids); radial (R): perpendicular to longitudinal direction and parallel to radius of trunk and wood rays; and tangential (T): perpendicular to longitudinal direction and parallel to growth rings (FPL 1980). For that reason, values of $R$ and $\tau_{\gamma}$ should be applied accordingly to the cutting speed direction in regard to the wood grain direction (Jeronimidis 1980; Green et al. 1999; StanzlTschegg and Navi 2009), which is mainly a function of the sawing kinematics. Equation (4) is solved numerically (Orlowski and Ochrymiuk 2010).

The chip acceleration power $P_{\text {ac }}$ variation as a function of mass flow and tool velocity is given by:

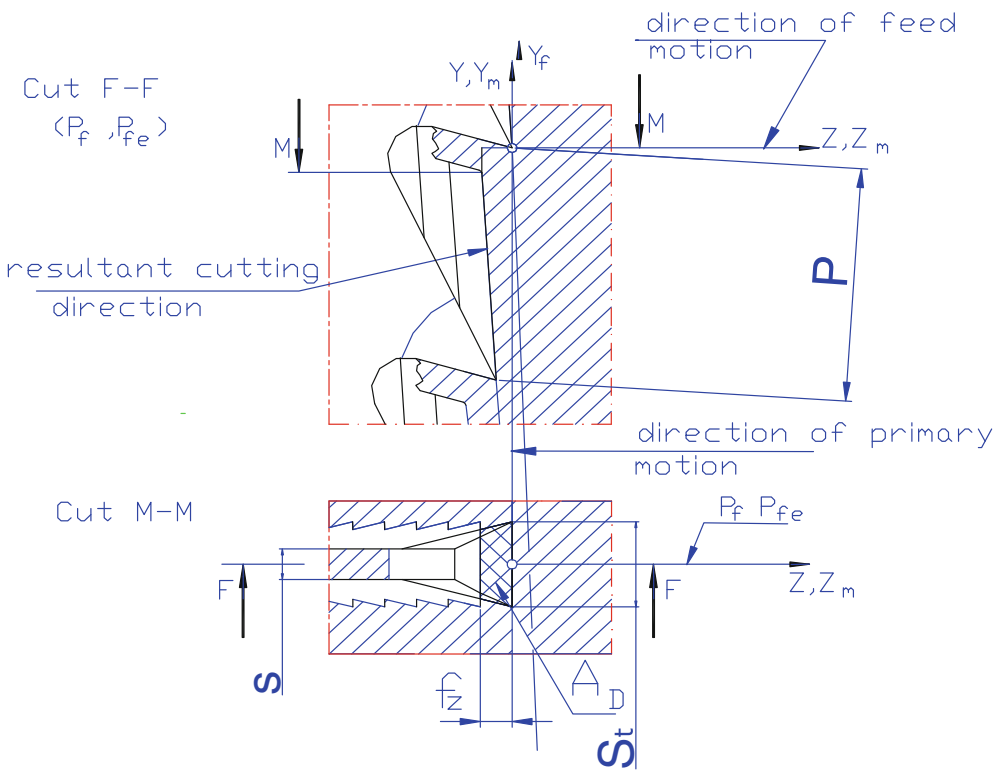

Fig. 2 Sawing kinematics on the sash gang saw and band sawing machine: $f_{\mathrm{Z}}$ feed per tooth, $s$ saw blade thickness, $A_{\mathrm{D}}$ area of the cut, $P$ pitch, $Y, Z$ and $Y_{\mathrm{M}}, Z_{\mathrm{M}}$ machine coordinate and setting axes, $Y_{\mathrm{f}} f$-set coordinate axis, $P_{\mathrm{fe}}$ working plane 
Fig. 3 Tooth cutting edge principal positions and cutting speed directions (adapted from Laternser et al. 2003)

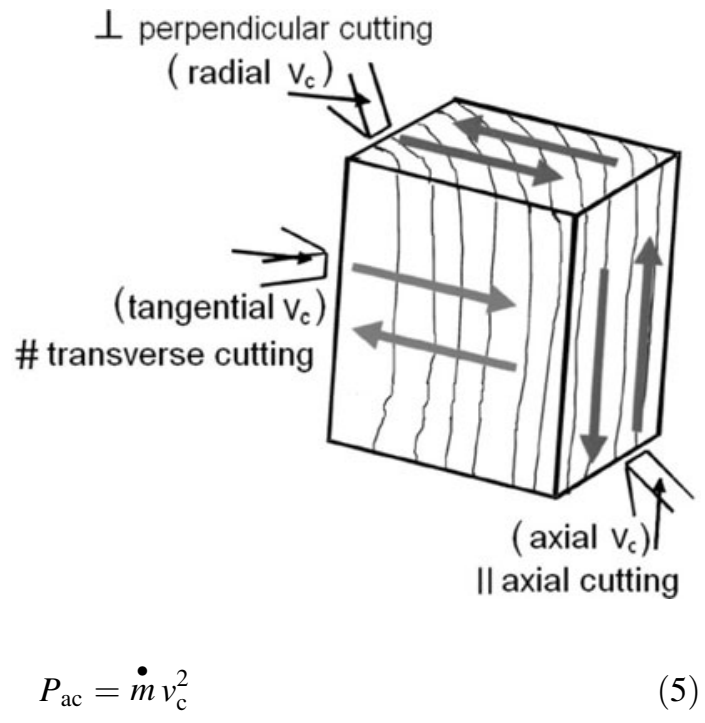

where $\dot{m}\left(\mathrm{kgs}^{-1}\right)$ represents the mass of wood (chips) evacuated in a certain period of time at a certain cutting tool velocity $v_{\mathrm{c}}$ (cutting speed), which can be calculated as follows:

$$
\dot{m}=H_{\mathrm{P}} S_{\mathrm{t}} v_{\mathrm{f}} \rho
$$

In Eq. (6), $v_{\mathrm{f}}$ is feed speed and $\rho$ is density of sawn wood. It should be emphasized that in these analyses, it was assumed that the power $P_{\mathrm{ac}}$ is not a function of the number of working teeth.

Kinematics of sawing on circular sawing machines (Fig. 4) differs from kinematics of cutting on sash gang saws and band sawing machines. In case of cutting with circular saw blades, uncut chip thickness $\bar{h}$ (e.g. an average value) instead of feed per tooth $f_{\mathrm{z}}$ should be taken into account; hence, the cutting power may be expressed as:

$$
\bar{P}_{\mathrm{cw}}=F_{\mathrm{c}} v_{\mathrm{c}}+P_{\mathrm{ac}}=\left[z_{\mathrm{a}} \cdot \frac{\tau_{\gamma} S_{\mathrm{t}} \gamma}{Q_{\text {shear }}} v_{\mathrm{c}} \bar{h}+z_{\mathrm{a}} \cdot \frac{R S_{\mathrm{t}}}{Q_{\text {shear }}} v_{\mathrm{c}}\right]+P_{\mathrm{ac}}
$$

where $z_{\mathrm{a}}=\left(\frac{\varphi_{2}-\varphi_{1}}{\varphi_{\mathrm{t}}}\right)$ is the number of teeth being in contact with the kerf (average), $\varphi_{1}$ is an angle of teeth entrance which is given by $\varphi_{1}=\arccos \frac{2\left(H_{\mathrm{p}}+a\right)}{D_{\mathrm{cs}}}, \varphi_{2}$ is an exit angle which can be determined as $\varphi_{2}=\arccos \frac{2 a}{D_{\mathrm{cs}}}, D_{\mathrm{cs}}$ is a diameter of circular saw blade, an average uncut chip thickness is given by $\bar{h}=f_{\mathrm{z}} \sin \bar{\varphi}$, and an average angle of tooth contact with a workpiece $\bar{\varphi}$ is calculated from $\bar{\varphi}=\frac{\varphi_{1}+\varphi_{2}}{2}$.

Furthermore, it is difficult to assume that in this kind of sawing kinematics, there is a case of perpendicular cutting, because the angle between the grains and the cutting speed direction differs from $90^{\circ}$, as it was assumed for the sash gang saw and the band sawing machines. Hence, taking into account the position of the 


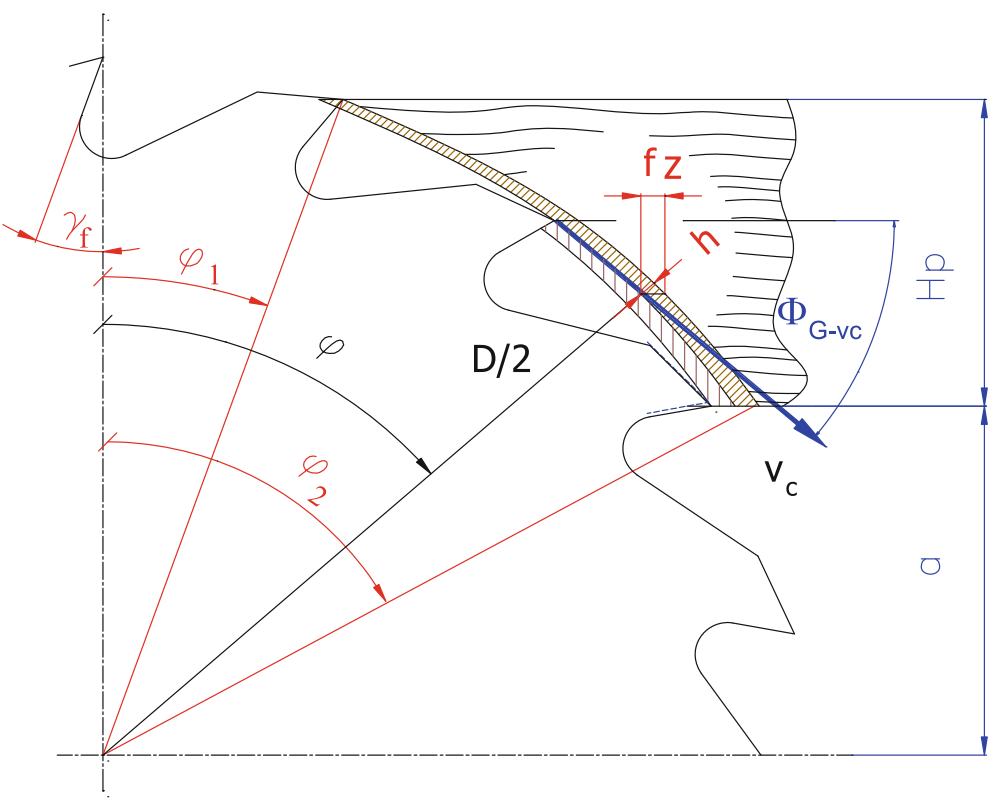

Fig. 4 Sawing kinematics on circular sawing machine: $f_{z}$ feed per tooth, $D$ circular saw blade diameter, $h$ uncut chip thickness, $H_{\mathrm{p}}$ workpiece height (depth of cut), $a$ position of the workpiece, $\varphi$ angular tooth position, $\Phi_{\mathrm{G}-\mathrm{vc}}$ an angle between grains and the cutting speed direction

cutting edge in relation to the grains, for indirect positions of the cutting edge fracture toughness $R$ and the shear yield stress $\tau_{\gamma}$ may be calculated from formulae known from strength of materials (Orlicz 1988). For example for cutting on circular sawing machines (a case of axial-perpendicular cutting), these material features are as follows:

$$
R_{\| \perp}=R_{\|} \cos ^{2} \Phi_{\mathrm{G}-\mathrm{vc}}+R_{\perp} \sin ^{2} \Phi_{\mathrm{G}-\mathrm{vc}}
$$

and

$$
\tau_{\gamma \| \perp}=\tau_{\gamma \|} \cos ^{2} \Phi_{\mathrm{G}-\mathrm{vc}}+\tau_{\gamma \perp} \sin ^{2} \Phi_{\mathrm{G}-\mathrm{vc}}
$$

where $\Phi_{\mathrm{G}-\mathrm{vc}}$ is an angle between grains and the cutting speed direction (Fig. 4).

\section{Material and examined sawing machines data}

Predictions of cutting powers have been made for the case of sawing on three types of basic sawing machines such as the sash gang saw (HDN, f. EWD), the band sawing machine (EB 1800, f. EWD) and the circular sawing machine (HVS R200, f. HewSaw), which are used in Polish sawmills. The basic sawing machines data and cutting parameters for which computations were done are shown in Table 1. Computations were carried out in each case for one saw blade. The raw material was pine wood (Pinus sylvestris L.) of depth of cut equal to $H_{p}$ (Table 1) derived from 
the Baltic Natural Forest Region in Poland. The indispensable raw material data for computation such as fracture toughness $R_{\perp}=840 \mathrm{Jm}^{-2}$ and the shear yield stress $\tau_{\gamma \perp}=22,636 \mathrm{kPa}$ were determined according to the methodology described in the works by Orlowski and Atkins (2007) and Orlowski and Palubicki (2009). The latter data determination tests of raw material were carried out on the sash gang saw PRW15 M (Wasielewski and Orlowski 2002; Orlowski 2010) with stellite tipped saw blades with a kerf equal to $S_{\mathrm{t}}=2 \mathrm{~mm}$. The average density of samples was $\rho=525 \mathrm{kgm}^{-3}$ at moisture content MC 8.5-12\%. The value of friction coefficient $\mu=0.6$ for dry pine wood was taken from the work by Beer (2002). The chip acceleration power $P_{\mathrm{ac}}$ variation was estimated for each kind of sawing kinematics for depth of cut equal to $H_{\mathrm{p}}=100 \mathrm{~mm}$.

In the case of circular sawing in which indirect positions of the cutting edge are present, $R$ and $\tau_{\gamma}$ have to be calculated from formulae (8) and (9). According to Aydin et al. (2007), it was assumed that fracture toughness for pine for longitudinal (axial) cutting $\mathrm{R}_{\|}=0.05 \mathrm{R}_{\perp}$. Moreover, an assumption was made that in case of pine wood for axial cutting, the shear yield stress $\tau_{\gamma \|}$ is equal to $0.125 \cdot \mathrm{MOR}$ [modulus of rupture in bending (Green et al. 1999; Krzysik 1974)]. The average value of MOR for pine wood derived from the Baltic Natural Forest Region (PL) was equal to MOR = 41.6 MPa (Krzosek et al. 2008; Krzosek 2009). Hence, at the tooth position of the circular saw equal to an average angle of tooth contact with a workpiece $\bar{\varphi}$, fracture toughness was equal to $R_{\| \perp}=714 \mathrm{Jm}^{-2}$ and the shear yield stress was $\tau_{\gamma \| \perp}=9,559 \mathrm{kPa}$.

\section{Results and discussion}

Predictions of cutting model that includes work of separation in addition to plasticity and friction in the case of sawing dry pine wood on examined sawing

Table 1 Tool and machine tool data

\begin{tabular}{llll}
\hline Parameter & $\begin{array}{l}\text { Sash gang saw } \\
\text { HDN (f. EWD) }\end{array}$ & $\begin{array}{l}\text { Circular sawing machine } \\
\text { HVS R200 (f. HewSaw) }\end{array}$ & $\begin{array}{l}\text { Band sawing machine } \\
\text { EB 1,800 (f. EWD) }\end{array}$ \\
\hline$H_{\mathrm{p}}(\mathrm{mm})$ & 140 & 80 & 140 \\
$S_{\mathrm{t}}(\mathrm{mm})$ & 4.0 & 3.6 & 3.1 \\
$P(\mathrm{~mm})$ & 25 & - & 50 \\
$\gamma_{f}\left({ }^{\circ}\right)$ & 14 & 22 & 28 \\
$z(-)$ & 32 & 24 & 217 \\
$v_{\mathrm{c}}(\mathrm{m} / \mathrm{s})$ & 6.4 & 64.14 & 35 \\
$v_{\mathrm{f}}(\mathrm{m} / \mathrm{min})[(\mathrm{m} / \mathrm{s})]$ & $0-15(0-0.25)$ & $70-150(1.16-2.5)$ & $40-70(0.67-1.167)$ \\
$f_{\mathrm{z}}(\mathrm{mm})$ & $0-1.953$ & $1.23-1.56$ & $0.95-1.67$ \\
$h(\mathrm{~mm})$ & $0-1.953$ & $0.59-0.747$ & $0.95-1.67$ \\
$P_{\mathrm{EM}}(\mathrm{kW})$ & 160 & $2 \times 90$ & $4 \times 110$ \\
\hline$P$
\end{tabular}

$P$ pitch, $z$ teeth number, $P_{\text {EM }}$ power of installed electric motors 
machines are shown in Fig. 5. The reductions in $\Phi_{\mathrm{c}}$ (Fig. 5a) and increases in $\gamma$ (Fig. 5b) are visible in plots, which concerns what happens near the origin of both $\Phi_{\mathrm{c}}$ versus $h\left(f_{\mathrm{z}}\right)$ and $\gamma$ vs. $h\left(f_{\mathrm{z}}\right)$ plots. Those changes at small depths of cut are the reasons for the increase in cutting pressure for small values of feed per tooth (the socalled 'size effect') (Atkins 2003, 2009; Orlowski et al. 2010). Furthermore, an increase in shear plane angle $\Phi_{\mathrm{c}}$ is observed when rake angle $\gamma_{\mathrm{f}}$ has a larger value.

Figure 6 shows the chip acceleration power $P_{\mathrm{ac}}$ variations as a function of feed speed $v_{\mathrm{f}}$ and cutting speed $v_{\mathrm{c}}$ for the sash gang saw HDN (Fig. 6a), the circular sawing machine HSV R200 (Fig. 6b) and the band sawing machine EB1800
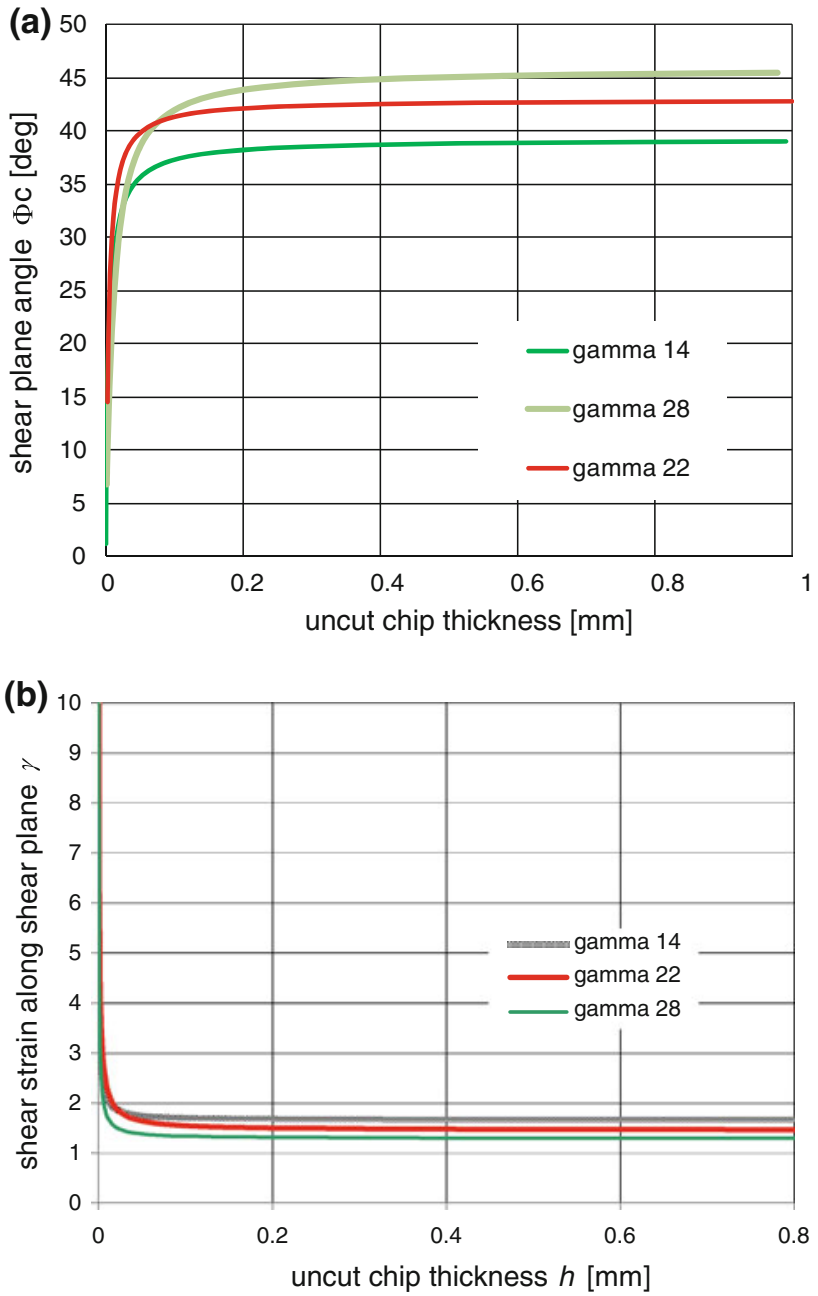

Fig. 5 Predictions of cutting model that includes work of separation in addition to plasticity and friction in the case of sawing dry pine wood on examined sawing machines (a) shear plane angle $\Phi_{\mathrm{c}}$ versus $f_{\mathrm{z}}$, (b) primary shear strain $\gamma$ versus $f_{\mathrm{z}}$, where gamma 14 (sash gang saw HDN), gamma 22 (circular sawing machine HSV R200), gamma 28 (band sawing machine EB1800) are rake angles 
(Fig. 6c) for the cutting processes with one saw blade while sawing dry pine wood for depth of cut equal to $H_{\mathrm{p}}=100 \mathrm{~mm}$. For sash gang saws, a maximum value of the chip acceleration power $P_{\mathrm{ac}}$ equals to $\cong 2.5 \mathrm{~W}$. Thus, in those machine tools where cutting speeds and feed speeds are rather small compared with circular saws and band saws, chip momentum may be disregarded, the same as in the case of metal cutting where it is customarily ignored (Atkins 2009). In case of both the circular sawing machine and the band sawing machine, the chip acceleration power $P_{\mathrm{ac}}$ is several hundreds larger in comparison with the sash gang saw.

Comparison of predictions of cutting powers obtained with the use of cutting models that include work of separation in addition to plasticity and friction, and chip acceleration power variation in the case of dry pine sawing with one saw blade for three examined typical sawing machines are shown in Fig. 7.
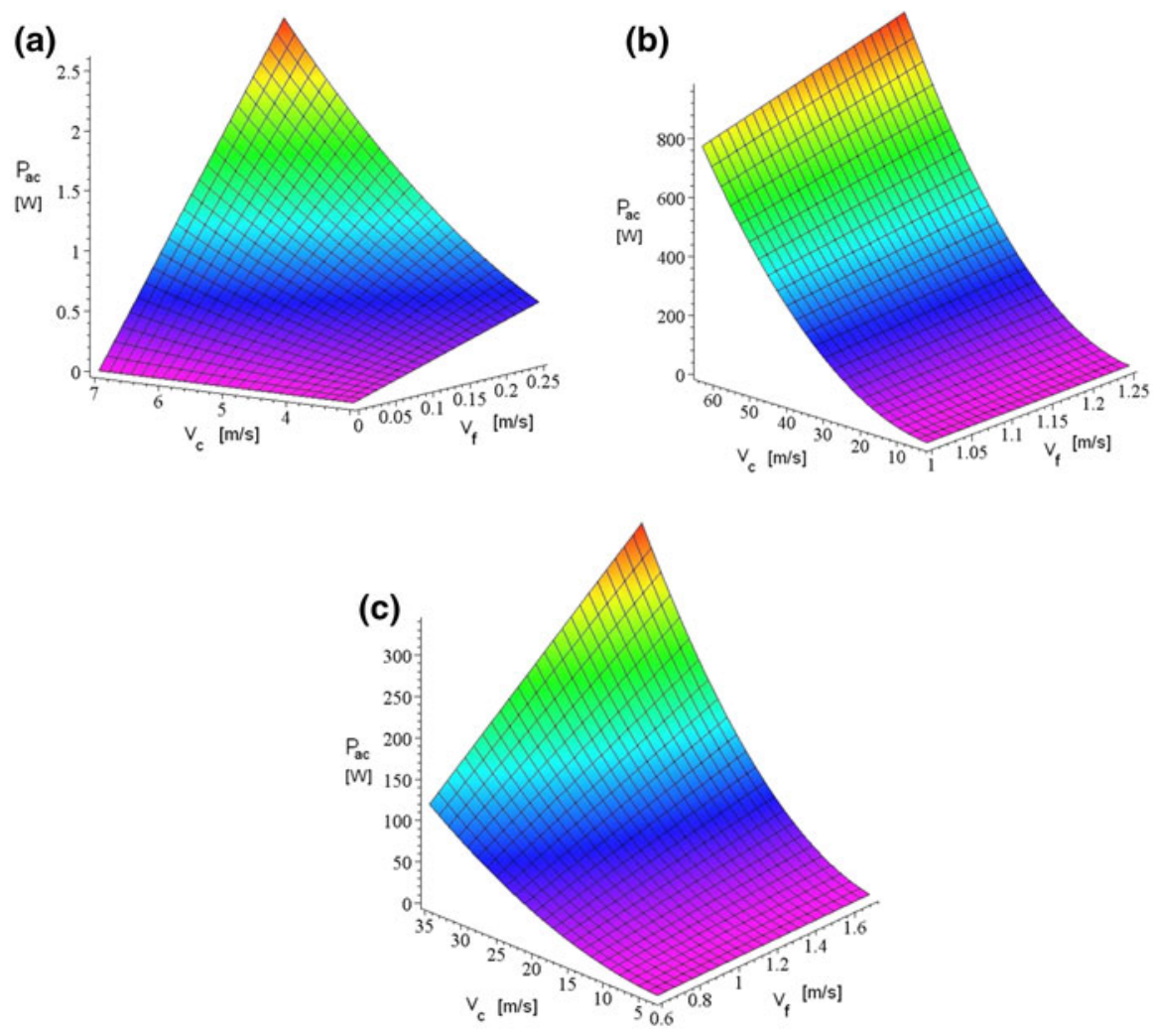

Fig. 6 Predictions of chip acceleration power variation $P_{\mathrm{ac}}$ as a function of cutting speed $v_{\mathrm{c}}$ and feed speed $v_{\mathrm{f}}$ for sawing of the pine workpiece of $100 \mathrm{~mm}$ in height with one saw blade on sash gang saw HDN (a), circular sawing machine HSV R200 (b) and band sawing machine EB 1800 (c) 


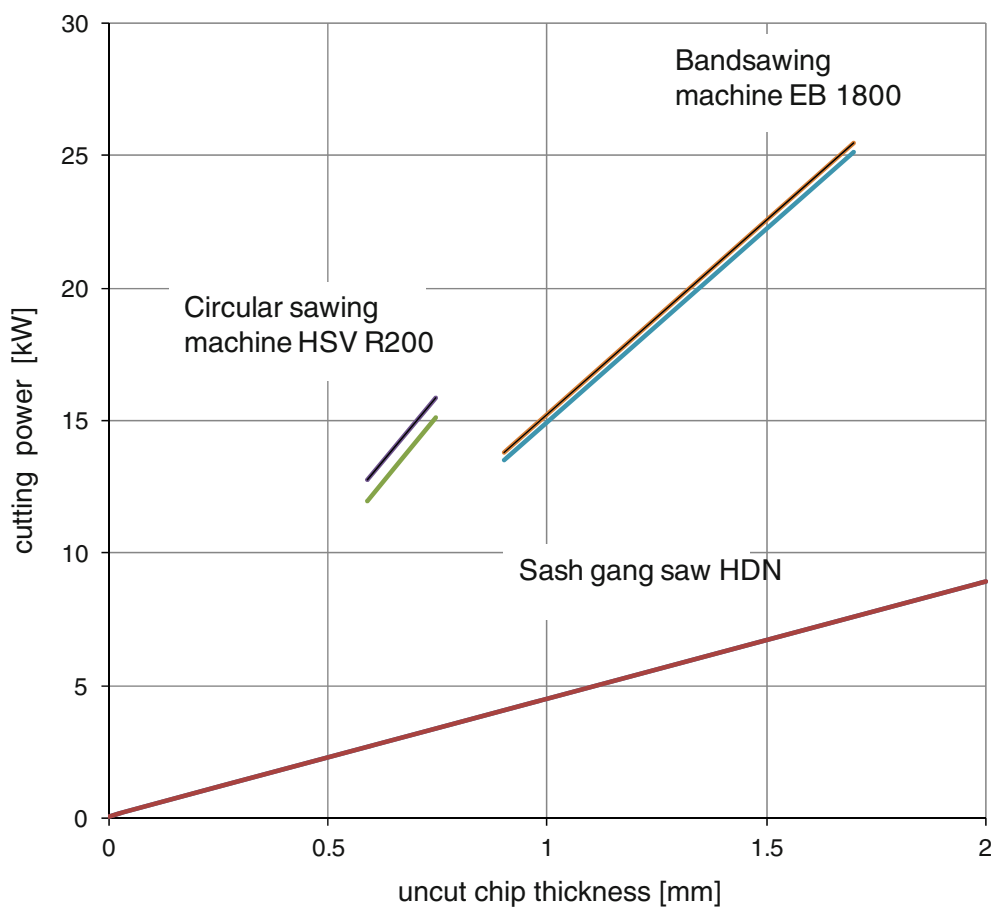

Fig. 7 Comparison of predictions of cutting powers obtained with the use of cutting models that include work of separation in addition to plasticity and friction (lower lines), with chip acceleration power variation added (upper lines, for the circular sawing machine course and the band sawing machine plot) in the case of dry pine sawing with one saw blade

Specific cutting resistance versus the method of power estimation

The predicted values of cutting powers were used for determination of the specific cutting resistance for each type of the sawing machine. In computations, the following formula was applied:

$$
k_{c}=\frac{P_{\mathrm{c}}}{S_{\mathrm{t}} \cdot H_{\mathrm{p}} \cdot v_{\mathrm{f}}}
$$

In the next step, the obtained results were compared with specific cutting resistances taken from the book by Manžos (1974) for all kinds of sawing machines, and additionally with calculated specific cutting resistances (Eq. 10) for the circular sawing machine and the band sawing machine on the basis of cutting power values received from the software accessible in the Internet (Web sources 1 and 2). The compared results are shown in Fig. 8a-c. This comparison revealed that the size effect is present for the cutting power prediction method which bases on the fracture mechanics (kc_FRAC) for each type of the machine tool and also in the case of circular sawing for Manžos's method (kc_Man, Fig. 8c). In all remaining cases, the scale effect is not imperceptible. This phenomenon has its roots in empirical 
formulae which are used. For example, Manžos (1974) recommend calculating specific cutting resistance for a band sawing machine in the case of pine sawing as follows:

$$
k_{\mathrm{c}}=9.91\left(5.3+0.01 H_{\mathrm{p}}-0.03 v_{\mathrm{f}}\right)
$$

where $H_{\mathrm{p}}$ is in $\mathrm{mm}$ and $v_{\mathrm{f}}$ is $\mathrm{m} \cdot \mathrm{min}^{-1}$.

On the other hand, Web sources 1 and 2 (2011a, b) for determination of the cutting power for both the band saw machine and the circular sawing machine apply the same formula in which the power is a function of the wood specific gravity $S G$. Thus, this kind of approach could be applied to rough estimations of cutting power while wood sawing, the more so because the correlation coefficients between strength properties (modulus of elasticity and density, bending strength and density and modulus of elasticity and bending strength) and wood density are in the range of 0.50-0.70. Moreover, the geographical location of the forest in which the trees were harvested strongly affects this correlation and timber grade (Krzosek 2009, 2011).

Obtained values of cutting powers (Fig. 7) for those machines seem to be reasonable when compared to the power $P_{\mathrm{EM}}$ of installed electric motors (Table 1). Furthermore, the specific cutting resistance is in conformity with values calculated using empirical calculation models (Fig. 8a-c). Hence, it has been proved that prediction of cutting powers obtained with the use of cutting models that include work of separation in addition to plasticity and friction together with the chip acceleration power variation is a useful tool for estimation of energetic effects of sawing of every kinematics.

\section{Cutting power normalization}

Since the cutting power for each kind of sawing machine has been calculated for different kerf values and also various workpiece heights (cutting depths, see Table 1) for a more general discussion the obtained results were normalized. The specific cutting power per one active tooth was calculated as follows:

$$
P_{\mathrm{c}}^{\prime 1}=\frac{P_{\mathrm{c}}}{S_{\mathrm{t}} \cdot z_{\mathrm{a}}}
$$

In the presented approach of energetic effects determination, the cutting power consists of three main terms (see Eqs. 1,7): the first-combined with shearing and friction; the second-connected with work of separation (fracture toughness); and the third-incident with the chip acceleration. Contributions of those components to the total specific cutting power per one active tooth while pine wood sawing were computed, and the results are presented in Fig. 9. For lower values of uncut chip thicknesses (Fig. 9a) in the total specific cutting power per one tooth, the component connected with the work of separation is a dominant character whereas shearing with friction has much lower importance. The acceleration factor has no significance. On the other hand, for larger values of uncut chip thicknesses (Fig. 9b), the opposite phenomenon is observed in which the term connected with shearing is featured. 
Fig. 8 Specific cutting resistance comparison in case of a sawing on the frame sawing machine HDN, b sawing on the band sawing machine EB 1,800 and c sawing on the circular sawing machine HVS R 200 where: $k c \_F r a c$ predicted values with the use of cutting model that include work of separation in addition to plasticity and friction, $k c \_$Man empirical values from the literature (Manžos 1974), $k c \_w w w$ empirical values on the basis of the software results (Web source 1 and 2, 2011a, b)
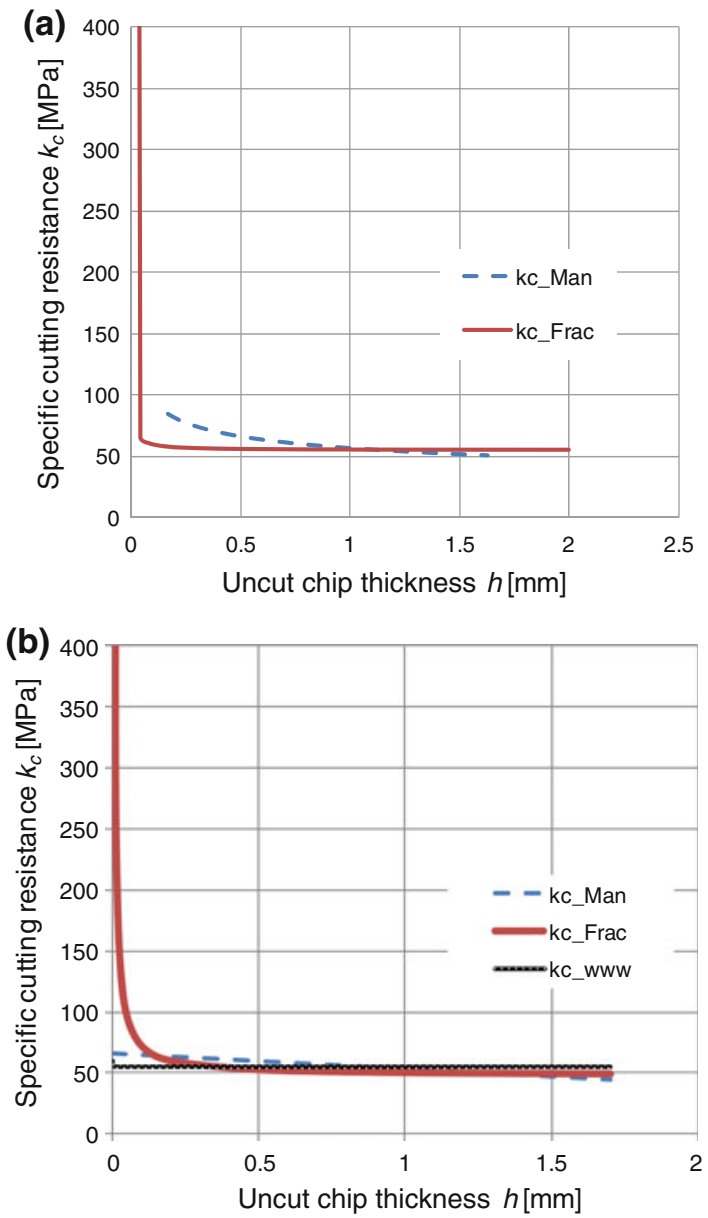

(c)

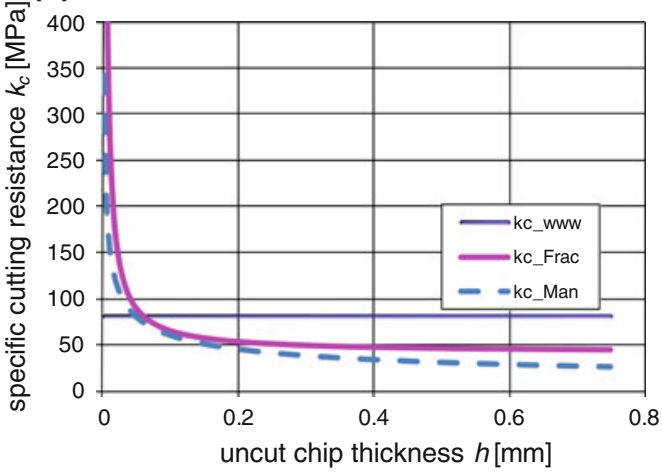

The normalization of the cutting power by the kerf value and number of active teeth allowed to explain that for the constant value of the uncut chip thickness, the specific cutting power for circular sawing machine is lower in comparison with the 
(a)

BSM $\square$ CSM $\square$ FSM
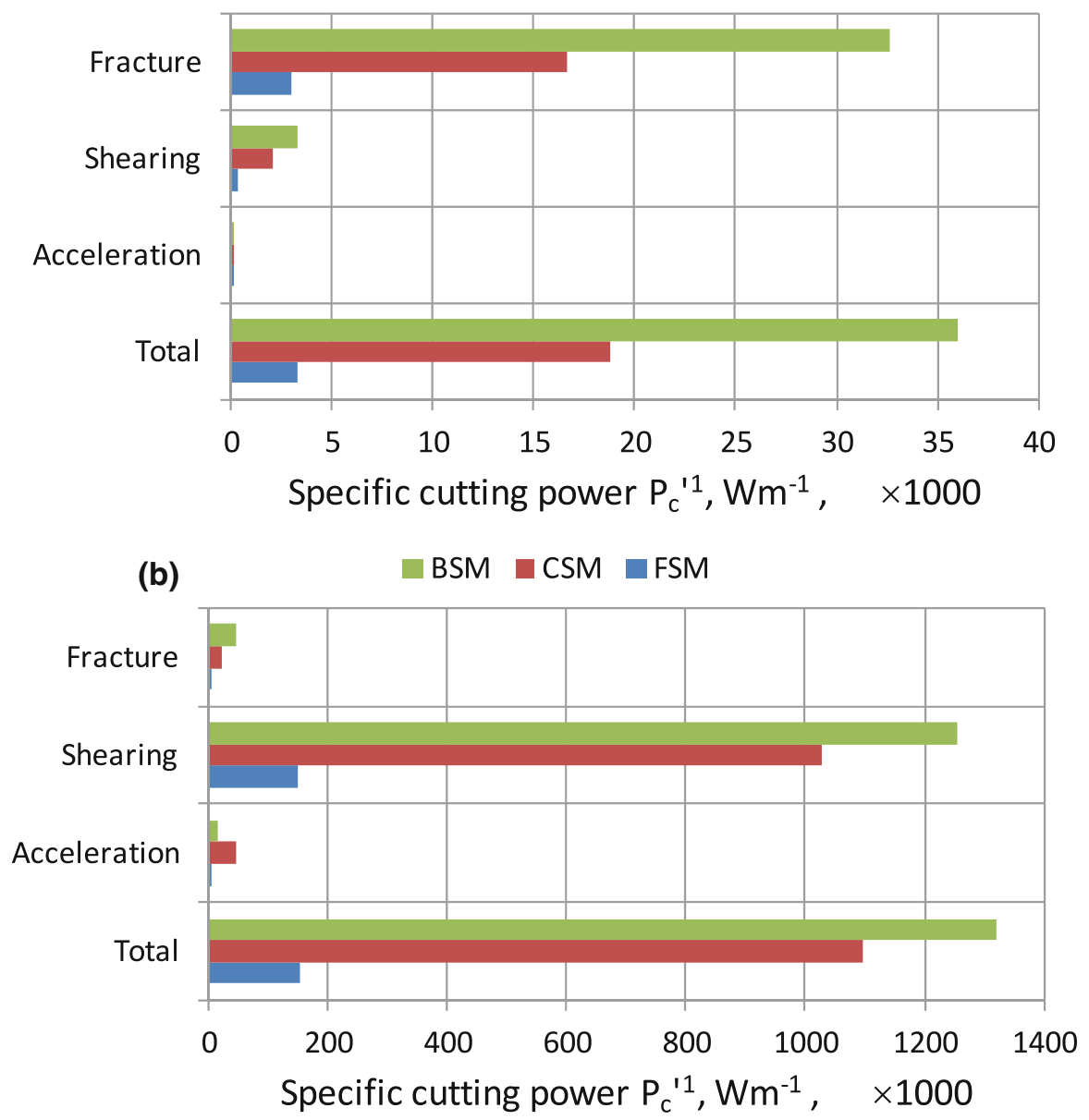

Fig. 9 Contributions of chip acceleration (Acceleration), fracture and shearing together with friction (Shearing) to the total specific cutting power per one active tooth while pine wood sawing on band sawing machine (BSM), circular sawing machine (CSM) and frame sawing machine (FSM) for uncut chip thickness $h=0.0075 \mathrm{~mm}$ (a) and $h=0.75 \mathrm{~mm}(\mathbf{b})$

band sawing machine, although the cutting speed is almost double, because the raw material properties during sawing with a circular saw blade are the result of a case of axial-perpendicular cutting.

\section{Conclusion}

The conducted analyses of energetic effects using cutting models that include work of separation in addition to plasticity and friction corroborated their versatility and revealed the usefulness for every known type of sawing kinematics. The analyses of 
the specific cutting resistance disclosed the presence of the size effect for each type of machine tool for the cutting power prediction method which bases on the fracture mechanics.

Moreover, in the estimation of cutting power for sash gang saws chip momentum may be disregarded. On the other hand, in case of cutting on band sawing machines and circular sawing machines, the chip acceleration power $P_{\mathrm{ac}}$ has to be taken into account.

Contributions of fracture, shearing together with friction and chip acceleration to the total specific cutting power per one active tooth while pine sawing depend on the uncut chip thickness. For low values of the uncut chip thickness, the component connected with the work of separation is a dominant character, whereas for larger values of this parameter, the term connected with shearing is featured.

Acknowledgement The authors would like to thank Dr. Sc. Krzosek S. (Faculty of Wood Technology, Warsaw University of Life Sciences-SGGW, PL) for the donation of the raw material used in tests.

Open Access This article is distributed under the terms of the Creative Commons Attribution License which permits any use, distribution, and reproduction in any medium, provided the original author(s) and the source are credited.

\section{References}

Agapov AI (1983) Dinamika processa pilenija drevesiny na lesopil'nych ramach. (In Russian: Dynamics of wood sawing on frame sawing machines), Kirovskij Politechničeskij Institut, Izdanije GGU, Gor'kij $^{\prime}$

Atkins AG (2003) Modelling metal cutting using modern ductile fracture mechanics: quantitative explanations for some longstanding problems. Int J Mech Sci 45:373-396

Atkins AG (2009) The science and engineering of cutting. The mechanics and process of separating, scratching and puncturing biomaterials, metals and non-metals. Butterworth-Heinemann is an imprint of Elsevier, Oxford

Aydin S, Yardimci MY, Ramyar K (2007) Mechanical properties of four timber species commonly used in Turkey. Turkish J. Eng. Env. Sci. 31(1):19-27

Beer P (2002) Obróbka skrawaniem obwodowym drewna nowo opracowanymi narzędziami (In Polish: Wood peeling with new elaborated tools). Roczniki Akademii Rolniczej w Poznaniu, Rozprawy Naukowe, Zeszyt 330. Wydawnictwo Akademii Rolniczej im. Augusta Cieszkowskiego w Poznaniu, Poznań

Dmochowski J (1981) Podstawy obróbki skrawaniem. (In Polish: Fundamentals of machining). Państwowe Wydawnictwo Naukowe, Warszawa

Fischer R (2004) Micro processes at cutting edge_-some basics of machining wood. In: Proceedings of the 2nd international symposium on wood machining, Vienna, Austria. pp 191-202

Green D. W, Winandy JE, Kretschmann DE (1999) Mechanical properties of wood (Chapter 4). In: Wood handbook-wood as an engineering material. Forest products laboratory. Gen. Tech. Rep. FPLGTR-113. Madison, WI: U.S. Department of Agriculture, Forest Service, Forest Products Laboratory, p 463

Grotte KH, Antonsson EK (eds) (2008) Chapter 7.3: Machining processes. In: Springer handbook of mechanical engineering, Part B: Applications in mechanical engineering. Springer. pp 606-656

Jeronimidis G (1980) The fracture behaviour of wood and the relations between toughness and morphology. Proc. R. S. Lond. B 208:447-460

Krzosek S (2009): Wytrzymałościowe sortowanie polskiej sosnowej tarcicy konstrukcyjnej różnymi metodami. (In Polish: Strength grading of Polish structural sawn timber with different methods). Wydawnictwo SGGW, Warszawa, p 127

Krzosek S (2011) Timber strength grading of Pinus Sylvestris L. using a visual method according to Polish standard PN-82/D-94021 and German standard DIN 4074. Wood Research 56(3):435-440 
Krzosek S, Grześkiewicz M, Bacher M (2008): Mechanical properties of Polish-grown Pinus silvestris L. structural sawn timber. In: Gard WF, van de Kuilen JWG, End user's needs for wood material and products. COST E53 conference proceedings, 29th-30th of October 2008 Delft, The NetherlandsDelft: Delft University of Technology, pp 253-260

Krzysik F (1974): Nauka o drewnie. (In Polish: Wood science). PWN, Warszawa

FPL (Forest Products Laboratory) (1980) Structure of wood. Research note, March. FPL-04, United States Department of Agriculture Forest Service

Laternser R, Gänser HP, Taenzer L, Hartmaier A (2003) Chip formation in cellular materials. Transactions of the ASME 125:44-49

Manžos FM (1974) Derevorežuŝie Stanki. (In Russian: Wood cutting machine tools). Izdatel'stvo "Lesnaâ promyšlennost'”, Moskva

Merhar M, Bučar B (2012) Cutting force variability as a consequence of exchangeable cleavage fracture and compressive breakdown of wood tissue. Wood Sci Technol 46(5):965-977

Merhar M, Bučar DG, Gospodarič B, Bučar B (2011) Orthogonal cutting as a method for the determination of fracture properties of oriented wood tissue. In: Grönlund A, Cristóvão L (eds) Proceedings of the 20th international wood machining seminar (Eds. ), June 7-10, 2011, Skellefteå, Sweden. Luleá University of Technology, pp 286-304

Olszak W (2008) Obróbka skrawaniem. (In Polish: Machininig) Wydawnictwa Naukowo-Techniczne, Warszawa

Orlicz T (1988) Obróbka drewna narzędziami tnącymi. (In Polish: Wood machining with cutting tools) Skrypty SGGW-AR w Warszawie, Wydawnictwo SGGW-AR, Warszawa

Orlowski K (2007) Experimental studies on specific cutting resistance while cutting with narrow-kerf saws. Advances in Manufacturing Science and Technology. 31(1):49-63

Orlowski KA (2010) The fundamentals of narrow-kerf sawing: the mechanics and quality of cutting. Publishing house of the Technical University in Zvolen, Technical University in Zvolen

Orlowski KA, Atkins A (2007) Determination of the cutting power of the sawing process using both preliminary sawing data and modern fracture mechanics. pp. 171-174. In: Navi P, Guidoum A (eds) Proceedings of the third international symposium on wood machining. Fracture mechanics and micromechanics of wood and wood composites with regard to wood machining, 21-23 May, Lausanne, Switzerland. Presses Polytechniques et Universitaires Romandes, Lausanne

Orlowski KA, Ochrymiuk T (2010) The prediction method of the shear angle in the cutting zone during wood sawing. Ann. WULS-SGGW, Forestry and Wood Technology 72:99-102

Orlowski KA, Pałubicki B (2009) Recent progress in research on the cutting process of wood. A review COST Action E35 2004-2008: wood machining-micromechanics and fracture. Holzforschung 63:181-185

Orlowski KA, Ochrymiuk T, Atkins A (2010) Specific cutting resistance while sawing of wood-the size effect. Ann. WULS-SGGW, Forestry and Wood Technology 72:103-107

Pantea RC (1999) Wood cutting system: modelling and process simulation. Mémoire présen té à la Faculté des études supérieures de l'université Laval pour l'obtention du grade de maître ès science (M.Sc.). Département de génie mécanique Faculté des Sciences et de genie, université laval, (National Library of Canada)

Scholz F, Duss R, Hasslinger R, Ratnasingam J (2009) Integrated model for the prediction of cutting forces. pp. 183-190. In: Handong Zhou, Nanfeng Zhu, Tao Ding (eds) Proceedings of 19th international wood machining seminar, October 21-23, Nanjing, China, Nanjing Forestry University

Stanzl-Tschegg SE, Navi P (2009) Fracture behaviour of wood and its composites. A Review Selected articles from the COST Action E35: wood machining-micromechanics and fracture. Selected articles from the COST Action E35: wood machining-micromechanics and fracture. Holzforschung 63(2009):139-149

Wasielewski R, Orlowski K (2002) Hybrid dynamically balanced saw frame drive. Holz Roh- Werkst 60:202-206

Web source 1 (2011) http://www.woodproductsonlineexpo.com/content.php/677/2160/wood_products_ bandmill_calculator.html.Accessed December, 2011

Web source 2 (2011) http://www.woodproductsonlineexpo.com/content.php/678/2173/wood_products_ gang_edger_calculator.html. Accessed December, 2011

Williams JG (1998) Friction and plasticity effects in wedge splitting and cutting fracture tests. J of Materials Science 33:5351-5357

Williams JG, Patel Y, Blackman BRK (2010) A fracture mechanics analysis of cutting and machining. Eng Fract Mech 77(2):293-308 